\title{
The processes of construction, deconstruction and reconstruction of an IFSC English language teacher's professional identity
}

\author{
0 processo de construção, desconstrução e reconstrução da \\ identidade profissional de uma professora \\ de inglês do IFSC
}

Fernanda Ramos MACHADO

(Instituto Federal de Santa Catarina/Universidade Federal de Santa Catarina)

Gloria GIL

(Universidade Federal de Santa Catarina)

\section{ABSTRACT}

This article presents a qualitative study which aimed at investigating the process of identity construction of Silvana, an English language teacher from the Federal Institute of Santa Catarina (IFSC). In order to do so, data were generated from class observations, field notes and an interview and analysis consisted in a long and careful process of reflection, subjective interpretation and construction of meanings from the data generated in interaction with the theories that support this study. Regarding the latter, we have drawn mainly on the contributions of Wenger (1998), Connelly \& Clandinin (1999) and Gee (2000-2001) who present complementary views regarding the concept and construction of identities. As for the methodology, we aimed at describing the events from an emic perspective in order to gain a deeper understanding of the meanings that events had for the participant. Therefore, data were generated from class observations, field notes and an interview with Silvana. Results show that there is a complex web of issues interacting in the process of Silvana's professional identity construction. The entire process involves a movement of construction, deconstruction and reconstruction of her professional identity and is strongly influenced by 
her professional landscape in interaction with previous personal, learning and professional experiences.

Key-words: Identity construction; English language teacher, Federal Institute of Santa Catarina.

\section{RESUMO}

Este artigo apresenta um estudo qualitativo que teve como objetivo investigar o processo de construção da identidade de Silvana, uma professora de Inglês do Instituto Federal de Santa Catarina (IFSC). Para tanto, os dados foram gerados de observações de aulas, notas de campo e uma entrevista e a análise consistiu de um longo e cuidadoso processo de reflexão, interpretação subjetiva e construção de significados a partir dos dados gerados em interação com as teorias que norteiam este trabalho. Com relação a este último, baseamos-nos principalmente em Wenger (1998), Connelly \& Clandinin (1999) e Gee (2000-2001), autores que apresentam visões complementares sobre o conceito e a construção das identidades. Quanto à metodologia, buscamos descrever os eventos a partir de uma perspectiva êmica, a fim de obter uma compreensão mais profunda dos significados que os eventos tiveram para a participante. Portanto, os dados foram gerados a partir de observações de aula, notas de campo e uma entrevista com Silvana. Os resultados mostram que há uma complexa teia de fatores que interagem no processo de construção da identidade profissional de Silvana. Este processo envolve um movimento de construção, desconstrução e reconstrução de sua identidade profissional e é fortemente influenciado por sua paisagem profissional em interação com experiências pessoais, de aprendizagem e profissionais anteriores ao IFSC.

Palavras-chave: Construção de identidade; professor de língua inglesa; Instituto Federal da Santa Catarina.

\section{Introduction}

There has been a growing number of authors interested in examining the topic of language teacher identity (Pavlenko, 2003; Morgan, 2004; Varguese et al 2005; Tsui, 2007; Atay \& Ece, 2009; Zacharias, 2010; Trejo-Guzman, 2010; Kanno \& Stuart, 2011; e Bukor, 2011) for it has 
been considered a crucial element to better understand what goes on in the classroom and to inform the designing of additional language teacher education programs. According to Assis-Peterson (2008), a perspective to the teaching and learning of additional languages that goes beyond the method started to gain space in the nineties, which allowed macro and micro contextual factors that influence teachers' practices in the classroom to be taken into consideration. In this perspective, the social actors and their subjectivities receive special attention, and "the very identity of the teacher starts to be seen as a central component in the sociocultural and sociopolitical scenario of the classroom and of the teacher's professional development" (Assis-Peterson \& Silva, 2010:145 $)$. In this respect, Varguese et al (2005) emphasize that teachers play a crucial role in the constitution of classroom practices and that studies exploring teachers' knowledge, beliefs and attitudes acknowledge that such features could not be looked at separately, but it is teachers' whole identity that is at play in the classroom.

In the Brazilian context, there has also been an increasing number of studies investigating English language teachers professional identity as evidenced in recent publications (Telles, 2004, Silva et al, 2007; Reis et al, 2011; Barros \& Assis-Peterson, 2010; Barcelos \& Coelho, 2010; e Denardi \& Gil, 2015). Most of these studies have focused mostly on pre-service English language teachers taking a degree in English ${ }^{2}$ as well as English language teachers from regular public schools and from private language institutes. In Gamero's (2011) survey of thesis and dissertations written between 1985 and 2009, for instance, it is possible to notice that. However, not a single study was found investigating the topic of English language teacher identity in the context of a federal institution of professional and technological education, even though it is the education network that expands the most in Brazil (Ministério da Educação, 2015). In the state of Santa Catarina alone, there are currently seven times more Federal Institutions of Education, Science and Technology of Santa Catarina (IFSC) than it used to in 2006, totaling 22 campi spread all over the state. In addition to that, IFSC is a self-governed public institution which offers professional

1. Our translation for "a própria identidade do professor passa a ser vista como um componente central no cenário sociocultural e sociopolítico da sala de aula e do desenvolvimento profissional do professor".

2. Our translation for Licenciatura em Letras Inglês. 
and technological qualification and education in different teaching levels and modalities, through the integration of teaching, research and extension, aiming at the citizens' professional performance in the diverse economic sectors, specially the local, regional and national socioeconomic development (Brasil, 2008).

As one can foretell, working at IFSC offers a whole new array of challenges to both experienced and novice English language teachers. In the campus where this study took place, located in the East region of Santa Catarina, such challenges involve teaching General English and English for Specific Purposes (ESP) to different levels of education ${ }^{3}$, coping with the specificities of each of the courses, carrying out research and outreach projects, assuming administrative positions and participating in working groups.

In face of the lack of research on English language teacher identity (re) construction in the context of IFSC and the challenges that these teachers face in this context, the objective of this study, which is part of a broader research project, is to weave interpretations regarding the process of Silvana's ${ }^{4}$ professional identity construction, an English language teacher of secondary, technical and technological education who has been working at IFSC for more than seven years. In order to do so, we firstly present a few authors who have theorized about the concept and formation of identities. Then, we describe the methodology adopted for data generation and analysis. Next, we retell the story of Silvana and then we analyze and discuss the data, focusing on the issues that interact in the process of Silvana's professional identity construction. Finally, we offer some final remarks.

\section{Theoretical Framework}

Some studies have reported how different societies in different historical periods have emphasized different perspectives on identity (Bukor, 2011; Castañeda, 2011; Trejo-Guzman, 2010; Block, 2007; Gee, 2000-2001; e Hall (1996). Block (2007), who comes from the 
field of education, states that "there has been a movement from a preoccupation with stability, function and structure to a priming of individual agency and a shift from fixed essentialized (...) categories such as race, ethnicity, gender and age to a generally constructivist perspective which sees these categories as more fluid and unstable" (p. 3). According to the author, this movement or shift is characteristic of the poststructuralist way of thinking and has come as a response to biological determinism and social structuralist approaches to research identity. In the same vein, Hall (1996) postulate that institutional and structural changes are not only transforming modern societies in the late twentieth century but also the very process of identity formation, making it more open-ended, variable and problematic. These transformations give way to the emergence of the post-modern subject whose identity is not fixed or stable but fragmented, constituted by multiple and sometimes contradictory identities, and in constant flux.

For Gee (2000-2001), identity is constituted in an individual's specific experiences within specific discourses and his/her own narrativization of these experiences, which allows him/her being recognized as a certain kind of person in a given time and space. The author emphasizes that "The "kind of person" one is recognized as "being" at a given time and place, can change from moment to moment in the interaction, can change from context to context, and, of course, can be ambiguous or unstable" (Gee, 2000-2001:100). Regarding the constitution of identity, Gee (2000-2001) presents four perspectives through which we can "focus our attention on different aspects of how identities are formed and sustained" (p.101), namely: the nature perspective (or $\mathrm{N}$-identity), the institutional perspective (or I-identity), the discursive perspective (or D-identity) and the affinity perspective (or A-identity). From the four perspectives, the I-identity and the D-identity are particularly important to the present study. Regarding the institutional perspective, it understands identity as determined by institutional forces. In other words, institutions come to ensure that an individual is recognized as a certain kind of person. Gee (2000-2001) explains that I-identity can be a calling or an imposition depending on how actively or passively an individual performs his/ role in that position. The discursive perspective, in turn, posits that it is in the discourse and dialogues of others with whom he/she interacts that 
he/she gets recognized as a certain type of person and can construct and sustain one or more identities. According to Gee (2000-2001), D-identities can be seen as an ascription in case such identities were merely ascribed to that person. Conversely, D-identities can also be seen as an achievement if such identities were an active accomplishment of him/her.

Contributions regarding the concept and constitution of identity also come from Connelly and Clandinin (1999), who have been researching the topic of teacher knowledge since 1970 and for whom knowledge, context and identity are intricately related. These authors refer to identity as 'stories to live by'. They explain that "Stories to live by $(. .$.$) is given meaning through the narrative understanding of$ knowledge and context" (Connelly \& Clandinin, 1999:4). For them, teacher knowledge, that is, their personal practical knowledge, is seen as personal and social narratives of experience which reflect both the history of their life and the contexts in which they live. In relation to context, Connelly and Clandinin (1999) refer to the school context specifically understood metaphorically as a professional knowledge landscape, a landscape that is narratively constructed and "composed of relationships among people, places and things" (Connelly \& Clandinin, 1995:4-5, as cited in Connelly \& Clandinin, 1999:2). In this respect, the authors explain that a professional knowledge landscape is composed of two fundamentally different places: the out-of-classroom place, where teachers are expected to live the school's sacred stories and the in-classroom place which refers to the place where teachers generally feel safe and free to live their secret stories (Connelly \& Clandinin, 1999). The authors also explain that when teachers move to the out-ofclassroom place they might live and tell cover stories, which are stories in which teachers depict themselves as fitting into the story of school that the school decided to live by. In this sense, for Connelly and Clandinin (1999:4), secret, sacred and cover stories shape teachers' identities.

Wenger (1998) is another author whose theorizations bring valuable contributions for making sense of the process of identity construction of the participant of the present study. This author proposes a social theory of learning where learning is understood as social participation, i.e., individuals' active involvement in the practices of social communities. For Wenger (1998), identity and practice are deeply connected as 
Developing a practice requires the formation of a community whose members can engage with one another and thus acknowledge each other as participants. As a consequence, practice entails the negotiation of ways of being a person in that context (...). In this sense, the formation of a community of practice is also the negotiation of identities. (p. 149).

In this line of thought, making a parallel between practice and identity, Wenger (1998) defines identity as: negotiated experiences, community membership, learning trajectory, nexus of multimembership and a relationship between the local and the global. For the purposes of this study, we briefly discuss the first three concepts.

Regarding identity as negotiated experience, the author states that "We define who we are by the ways we experience our selves through participation as well as by the ways we and others reify our selves" (Wenger, 1998:149). Regarding the terms participation and reification, Wenger (1998) explains that the former refers to the subjects' social experience of living in the world as members of communities of practice, negotiating a joint enterprise and creating their own resources in the pursuing of that enterprise. As for the latter, finding it helpful to provide Webster's definition of reification, meaning 'to treat an abstraction as substantially existing, or as a concrete material object', Wenger (1998) explains that he uses the concept of reification generally to refer to "the process of giving form to our experience by producing objects that congeal this experience into "thingness."”' (p. 58). Based on these two concepts, the author argues that identity is defined socially, that is, who one is is defined in the way he/she experiences his/her life daily through participation and reification and not solely in the way one thinks and says about him/herself or in the way others think or say about him/her.

Concerning identity as community membership, Wenger (1998) states that "We define who we are by the familiar and unfamiliar" (p. 149). The author explains that when an individual is a full member of a community of practice, his/her competence of mutual engagement, negotiation of a joint enterprise and development of a shared repertoire becomes dimensions of his/her identity. On the other hand, not being a full member of a community of practice also contributes to shaping 
who one is, i.e., people's identities are constituted by both what they are and what they are not.

In relation to identity as learning trajectories, Wenger (1998) states that "We define who we are by where we have been and where we are going" (p. 149). In this sense, as an individual experiences diverse forms of participation in the same or in different communities of practice, his/her identity forms trajectories which is understood as a continuous motion that connects past, present and future coherently. According to the author, there are five different types of trajectories, from which two are particularly relevant at the moment: the peripheral trajectory and the inside trajectory. Regarding the former, by choice or by necessity members of a community of practice may never become full members, i.e., they may choose to be non-participants of that community. As for the latter, full members of a community of practice never cease to renegotiate their identities because there are always new events, demands and intentions that lead them to do so. For Wenger (1998), understanding identity as learning trajectories is to understand the shifting and unstable nature of identities.

Finally, in line with Varguese et al (2005) who posit that a combination of theoretical frameworks is more likely to better capture the complexity of teacher identity, we have decided to draw on the contributions of the aforementioned authors, namely, Wenger (1998), Connelly \& Clandinin (1999) and Gee (2000-2001) to give theoretical support to my interpretations. I doing so, we align to their views of identity construction just discussed. Therefore, at the same time that in this article we understand teachers' professional identities as narrative constructions that take shape as life unfolds and which are composed by stories teachers live and tell (Connelly \& Clandinin, 1999), we also acknowledge the profound connection between teachers' professional identities and practice where the negotiation of their professional identities take place as they engage in the practices of communities of practice (Wenger, 1998). In addition to that, we also take into consideration the role of discourse in the constitution of identities in the sense that teachers' professional identities are constructed in their discursive practices with the other (Gee, 2000-2001). 


\section{Methodology}

As has been previously stated, the objective of this study was to build meanings and interpretations regarding the process of Silvana's professional identity construction in the context of IFSC, the issues that interact and how they interact in this process. Silvana is an English teacher who majored in English from a federal university in northeast Brazil and has been working at IFSC for eight years. This study falls within the qualitative research paradigm once it involves an interpretive, naturalistic approach to the situation at hand and focuses on describing the events from the participants' points of view in order to gain a deeper understanding of the meanings that the events have to them (Denzin \& Lincoln, 2005). In this sense, we took the role of participant observer and participated in Silvana's daily life at IFSC for a period of a year and a half $(2014 / 2-2015 / 2)$, in order to offer a more holistic account of the phenomenon under investigation from an emic perspective, recognizing that our interpretations are always imbued of our personal, cultural and historical experiences. It is also important to state that in order to gain access to the context of study we have followed Creswell's (2007) ideas and established a good rapport with the participant. In our particular case this step was facilitated by the fact that one of the authors of this study was already inserted in the context of investigation since 2014/1, when she started working as an English language teacher there. The moment she started to work at IFSC she automatically developed a close and respectful relationship with her colleagues, not only Silvana, but also the other actors that compose the landscape of the campus. We also consider important to emphasize that this study has been submitted to the ethics committee and has been approved ${ }^{5}$. Furthermore, Silvana has read, agreed with and signed the consent form.

Croker (2009) argues that, in qualitative studies researchers use multiple methods for data generation, so that "a fuller, richer picture of the participants' perspective can be explored and represented" (p.8). This way, following Holliday (2007) who states that "strategies for collecting data have to develop in dialogue with the unfolding nature of social settings (...) and developing relation between the researcher 
and the other people in the research process" (p. 71), we have generated data through classroom observation, field notes and an interview.

Regarding the analysis of data, Dörnyei (2007) states that "qualitative research is fundamentally interpretive, which means that the research outcome is ultimately the product of the researcher's subjective interpretation of the data" (p. 38). This way, the analysis of data for the present study consisted in a long and careful process of reflection, subjective interpretation and construction of meanings from the data generated in interaction with the theories, already presented, that support this study. It is worth mentioning that our interpretive process followed the four stages presented by Holliday (2007), which includes a movement departing from the corpus of raw data which contains what the researcher has seen and heard (1), going to the next two stages where data is organized and categorized based on the researchers' search for natural divisions (2) and thus arranged under thematic headings (3), and finalizing with the researchers presentation of his/her interpretation of the data in the written work. During this process, we could recognize four thematic headings that emerged and which we named: 1) Challenges at IFSC; 2) Family experiences; 3) Learning experiences and 4) Professional experiences. However, even though we had already started to build a network of relations in our minds, we were still overwhelmed with the amount of information coming from different sources and presenting periods of Silvana's life randomly. In face of that, we wrote a chronological narrative of Silvana, starting out from her childhood with her families, passing through her experiences at school, at private English schools, at university, and arriving at her professional experiences prior to and at IFSC. Having completed this stage, the next step consists in presenting the data, which we did in a narrativized way as, according to Creswell (2007), qualitative researchers very often use the first-person pronoun and write the study as if it was a story. In doing so in this article, we firstly tell a brief story of Silvana so that readers can have an overall idea of some of her family, learning and professional experiences prior to and at IFSC which have participated in the construction of her professional identity. Then, we discuss Silvana's experiences in her professional landscape at IFSC, entwining these with her past family, learning and professional experiences and turn to the theoretical framework presented in the previous section to provide structure to my interpretations. All along the 
discussion we try to make Silvana's voice as present as possible trough excerpts and vignettes taken from the interview and field notes.

\section{Getting to know Silvana}

\section{The story of Silvana before IFSC}

Silvana experienced a regular family life until she was nine when her father unfortunately passed away. In face of that, Silvana and her brothers had to get used to take responsibilities as a grown up and the evenings were no longer reserved for family time as her mother had to change to night shifts at her job in order to be able to take the kids to school in the morning. For Silvana, these abrupt changes affected not only practical issues of everyday life, but mainly the family relationship, as she puts it "So it changed a lot, you know... This disruption and a certain distancing, when you start to see the person as the administrator of the house, so you lose that emotional bond"6 (Interview, February, 2015)

Silvana had also to face changes of school a number of times along her primary and secondary education. Among the reasons for so many school changes was the risk of Silvana failing the year because she was either dedicating too much time to the ballet or to her boyfriend. As reprimand, Silvana's mother decided to take her out from the ballet classes and put her in a different school which, to her mother's surprise, Silvana's performance in the entrance test granted her a place in the classroom of the most intelligent students and a $50 \%$ discount in the school's tuition. This way, Silvana, who had received the title of the black sheep of the family because of her struggles at school suddenly became the 'white sheep'.

Parallel to her primary and secondary education, Silvana also took English classes at a private English teaching institute (ETI) ${ }^{7}$. There, Silvana experienced feelings of hate and love about the English classes and the teachers. As a child, there was an English language

6. All translations were made by this author.

7. ETI is a pseudonym, as are all names for the private language schools throughout this article. 
teacher, called Catarina, who Silvana hated because she considered her unfriendly and whose classes she did not like to go and almost failed for absence. Coincidently, Catarina came to be Silvana's teacher again later on other occasions, one of them was at university where Catarina was responsible for the discipline of English Language Teaching Methodology in which Silvana was enrolled. Silvana really enjoyed her classes and they developed a very friendly relationship. At ETI, Silvana kept having negative experiences with English language teachers and their classes and kept skipping classes. Besides their unfriendliness, Silvana also disapproved teachers who put her in a situation where she felt uncomfortable or who were not amusing enough, as she puts it "I didn't go because I hated that teacher (...) I hated everything in that school, everything was boring and dull (...) I hated role plays, my God, I wanted to die!" (Interview, February, 2015). Silvana's demotivation made her fail in the English course for absence and for this reason her mother requested that Silvana was placed in a different class. In this new class Silvana recovered her love for the English classes. She was placed in a classroom "with crazy people, with a teacher who was even crazier (...) and I started to love to go to the English classes" (Interview, February, 2015). Regarding the student-teacher relationship, Silvana appreciated that "the teachers treated us all the same" (Interview, February, 2015).

By the age of 17, Silvana had completed English learning program at ETI and started to wonder about the possibilities that the English language could give her and thought "Wow, this English thing is cool, because it's not difficult and gives me money on top of that (...) What are my possibilities? (...) What can I do now? I'll give classes!!!" (Interview, February, 2015). She found out that at LTI, a private language teaching institution, offered a teacher training course and so she took the course and a month later she was having her first experience as an English language teacher. For her it was clear that she was doing that because it was a possibility of making easy money in a fun way until she tried the university entrance examination to the course which would become her real profession.

When Silvana finally got to the third year of secondary school, a new dilemma haunted her life: she had to make a decision regarding what to study at university. Her boyfriend tried to persuade her to 
study Law and her mother supported him. For her it was important that Silvana studied something that offered her good perspectives of employment. However, Silvana thought "You know what, the English Language undergraduate course is offered here and I'll do it because it won't give me much work (...) it won't disturb me" (Interview, February, 2015). Thus, Silvana applied for the English Language undergraduate course in a state university and was accepted. Parallel to entering the university, she decided to take the teacher training course at ETI by the end of which she was hired as a teacher. Having had a bad impression of the English Language undergraduate course in the first semester at university reinforced even more her idea that teaching English was just a casual work, an easy way to make money having fun, as she puts it "there wasn't anyone who was from the field and who wanted to pursue the teaching career (...) being an English teacher was just a casual work" (Interview, February, 2015).

However, in the second semester when the English Language module started, she fell in love with the course and then it became clear to her that she wanted to pursue the path of English language teaching. At university, Silvana once again had positive and negative experiences with professors. Positive experiences referred to a respectful and caring relationship between Silvana and her professors. The negative experiences referred to a relationship of distance and fear. In cases like these, she would rather give up the discipline and try it again with a professor with whom she got along well. For her, it is important that the professor be accessible to the students, that they do not feel afraid of getting closer and asking questions. Having graduated in English a year before the expected time and realizing she would not be able to find any position with just an undergraduate degree, she decided to apply for a Master's program, as she puts it "So, the Masters, it was not something I thought of doing since my undergraduate course. I thought, being very capitalist, practical, etc... what do I need in order to have a well paid job? (...)" (Interview, February, 2015). With the completion of the Master's Silvana was invited by a professor from a university in south Brazil to apply for the $\mathrm{PhD}$ program under her supervision in the area of phonetics and phonology. Silvana passed the selection and was granted a scholarship until the end of the program. 


\section{The story of Silvana at IFSC}

On her first day of work, Silvana did not receive any orientation from the school's pedagogical department or from the other English language teachers regarding the difference in the approach to English teaching (general English or ESP) depending on the level of education, neither did they introduce her to the school's overall objectives and facilities. Silvana was confused, insecure and feeling abandoned to her fate as expressed in her words "So it was like this, it was the students who told me how the English classes worked, because I really didn't receive ANY orientation" (Interview, February, 2015).

After a year and a half working at IFSC, Silvana was hired as a permanent teacher. Feeling more confident and familiarized with the demands from the institution, she offered to be the spokesperson of the foreign language office. She also submitted and coordinated two research projects, one about phonetics and the other about intelligibility. Frustrated with the lack of infrastructure to conduct the acoustic experiments with the students, she remarked "I wouldn't do that again!" (Interview, February, 2015).

Regarding the teaching of ESP, it was not all that clear to her what it meant to teach according to that approach. While still a student at university her professors had only superficially mentioned about ESP, explaining that it involved the teaching of reading strategies, such as skimming, scanning and previewing to facilitate the reading comprehension of texts specific to the areas of the learners. In her first experiences teaching ESP, she would look for specific texts and teach her students the same reading strategies she had learned during her teacher education. As time passed by she started to get advice from the teachers of specific areas and from the very students regarding what was important to teach. In this way, based on trial and error, by reflecting on her own practices and on the contributions from colleagues and students, Silvana is autonomously looking for better ways to work with ESP in her classes, as we can notice

I used to listen to other colleagues say 'I speak in English the whole class', and I thought 'So I guess I'm doing something wrong', so last year I tried it (...) but I noticed that it didn't work and it is working fine with this group now with the decision to (speak Portuguese in class) (...) So it was suggestions 
from the teachers and feedback from students who told me that. (Interview, February, 2015).

The challenges did not stop there. Silvana was invited to be the coordinator of the integrated technical courses where she had a terrible time, as she explains "it was an awful experience... because you still don't know very well how the institution works (...) and there's pressure coming from the parents, from the students, from the teachers" (Interview, February, 2015). After this negative experience, she reassumed the post of spokesperson whose responsibilities include attending to the department's meeting once a week, pass on the announcements to the group of language teachers, be attentive to the periods of auctions to purchase books, furniture, electronic equipment, etc., to cite a few. Silvana started to get tired of so much bureaucracy and frustrated with the difficulty of getting things done at IFSC. In addition to that, in the end of $2014 / 2$, the foreign language teachers found themselves having to justify the real necessity of having three language laboratories for their use only. Silvana got deeply disappointed for having to face this type of situation over and over again ever since she started working at IFSC, as I registered "Silvana says that since she has been working here she has seen the English team lose their classrooms twice, and that the thematic classes were difficult achievements and that she laments for such a setback" (Field Notes, October, 2015). Silvana also complained about the fact that when $\mathrm{CEFET}^{8}$ became IFSC, teachers started to be controlled regarding how they distributed their working hours and that they should get involved in research and outreach projects, publish articles, etc. For her, "it wasn't fun anymore (...) it started to get too bureaucratic" (Interview, February, 2015).

As an English language teacher at IFSC, Silvana is full of joy and her classes filled with relaxing moments, jokes and laughter. Also, "she is very spontaneous and does not waste an opportunity to start singing in the middle of the class when a word that makes her remember a song crosses her way" (Class observation, October, 2014). Silvana is

8. In March of 2008 a new bill of law allowed the transformation of the Centers of Technological Education (CEFET) into Federal Institutions of Education, Science and Technology. 
also quite open-minded, in the sense that she rarely calls her students attention if they are chatting, if they forget their material or even if any of them arrive in the last 20 minutes of the class. Therefore, it is very common to find students chatting around during her classes, not paying attention to what she is saying or doing the activities she proposes. Silvana rationally made the decision of not "wasting my time with these students" (Class observation, August, 2014) and focusing on the students who are interested in the class. In the department to which Silvana belongs, she is the person to whom colleagues higher in the hierarchy recur when any subject related to the foreign language teachers need to be discussed.

Silvana also acknowledges that becoming a mother was a turning point in her life. Not only did her priorities change, but also she became more sensitive to the other. Very often she finds herself in the middle of a dilemma between the mother who wants to spend more time with her kids and the teacher who was hired for a full time position. Recognizing that IFSC is a wonderful place to work, because it offers stability, a good salary and does not demand excessively from teachers, there are two strong reasons that make Silvana think of quitting her job or asking for a sabbatical leave: to participate more closely in her kid's childhood and to run away from all the bureaucracy involved in teachers' daily lives in the institution which result in frustration and demotivation.

Between 2013/2 and 2014/1 two new English language teachers joined the group of foreign language teachers, bringing their research backgrounds which Silvana automatically started to show interest to understand. For the first time she was getting in touch with postcolonial perspectives to language teaching and learning and terms such as additional language, English as lingua franca and intercultural competence started to sound more familiar to her. The new team of foreign language teachers also started to develop projects focusing on offering continuing education to foreign language teachers from public schools, besides attempting to design a MATESOL ${ }^{9}$ program to be offered at IFSC. Currently, Silvana finds herself on the verge of an important professional change: having to choose between sticking to her 
area of research where she is still a reference, being invited to participate as member of the committee in $\mathrm{MA}$ and $\mathrm{PhD}$ defenses; or follow a new path which she still does not know exactly what it is, but that is more in line with the reality she lives in her professional landscape.

\section{Discussion}

Silvana's story allows us, first, to see her through the lenses of Wenger's (1998) concept of identity as learning trajectories, in which identity is understood as "something we constantly renegotiate during the course of our lives" (p.154). This constant (re)negotiation of Silvana's identity can be noticed in her movements of participation and non-participation to different communities of practice during her learning experiences at ETI, the private English language school where she studied from the age of 9 until she was 17, and at university. When still an English language student at ETI, she was a participant member of communities of practice where teachers were friendly, accessible and fun and who "treated us all the same (...), they made jokes, they laughed, they liked to integrate with the others" (Interview, February, 2015). At university Silvana used to engage in the practices of communities where she could establish a good rapport with the teachers, as was the case of professor Catarina previously mentioned with whom Silvana developed relationship of mutual respect. By the same token, Silvana also opted for being a non-participant member of communities of practice where teachers "seemed to be from last century" (Interview, February, 2015) and who were unfriendly and indifferent towards students, forming this way a peripheral trajectory. For Wenger (1998), the combination of participation and non-participation "through which we define our identities reflects our power as individuals and communities to define and affect our relations to the rest of the world" (p.167). Both at ETI and at university Silvana used to express her power through subversive behavior, where she would intentionally skip the English language classes or give up the discipline in the undergraduate course until she met a professor with whom she could develop a nice relationship.

Also, when we look at Silvana's story at IFSC, still we can see the impact on the construction of her teacher identity in her participation and non-participation in communities of practice when she was still a 
student. The impact of those types of experiences on teachers' identities is encapsulated in the concept of apprentice of observation, a term coined by Dan Lortie (1975) to refer to the long period of time spent by student teachers while still schoolchildren developing perceptions about their teachers, their teachers' teaching and about what constitutes teaching practice (Borg, 2004), which eventually influences teachers' identities. This is also stressed by Brian \& Morgan (2015:21, as cited in Mattos, 2014), who suggest that “a teachers' emergent professional identity and her image of classroom possibilities is coloured by her own prior L2 learning experience..." (p. 135). In this sense, Silvana's previous experiences as a student with boring and inaccessible teachers on the one hand, and fun and friendly teachers on the other, helped to construct her professional identity. Therefore, from Silvana's narrative as an English language teacher at IFSC, emerges one important facet of her professional identity: that of an "spontaneous, fun and friendly teacher" (Field Notes, October, 2014).

Another important facet of Silvana's professional identity is that of an open-minded teacher, who deals with students in a very unorthodox and pragmatic way: she teaches only for those students who are interested in the classes and does not care and ignores those who are not. In relation to the last group of students, she expects them to be mature enough to realize the cause and effect relationship of their lack of commitment in class. As seen in the theoretical section, for Connelly \& Clandinin (1999), who understand identity as stories to live by, i.e, "narrative constructions that take shape as life unfolds (...)" (p. 95), the origin of a teacher identity can be seen in various aspects of his/ her life, such as his/her family life. The challenges that Silvana had to face due to her father's death demanded that she, likewise her mother, developed a practical attitude towards life which she extended to her professional life. In my interpretation, therefore, Silvana's family life serves as evidence for the origin of that facet of her professional identity: an overly open-minded teacher, who prefers not to waste her time with disinterested students.

Silvana's practical attitude towards life also influenced her decision to become an English teacher. For her, teaching English was just a casual job she would do to make money until she passed in the university entrance examinations for a higher status course. Silvana 
contributed to sustain a discourse identity (Gee, 2000-2001) ascribed to her, because that is how the identity of English teachers was constructed and sustained in the discourses of society and of English teachers who worked with her in private language schools. But then Silvana passes the university entrance examinations for the English language undergraduate course where, by the end of the second semester, she finally decided that being an English language teacher was what she really wanted to do professionally. From an ascribed identity, being an English language teacher became Silvana's achieved identity (Gee, 2000-2001), an identity that she had actively accomplished.

During her childhood and adolescence Silvana was also ascribed the discourse identity (Gee, 2000-2001) of the black sheep of the family. Silvana had priorities in life which diverged from those of her mother who wanted her to do well at school and later on choose a profession which would bring her financial return. In one of her changes of school, however, Silvana is placed in the classroom of the most intelligent students. She feels flattered with her new position but still a bit mistrustful in the beginning: "I got sort of flattered for being in the special class (...). In the end, (...) mathematics was easy (...) I don't know if it was for the fact that I was in the classroom of the special students and I started to believe in that (...) I found all that ridiculously easy" (Interview, February, 2015). Along the years other happenings in her life contributed to reinforce 'the new Silvana'. At university, she was once invited by professor Catarina to replace her in some classes. This invitation had a special meaning for Silvana because Catarina was the same teacher of when she almost failed the English language course for absence when still a child. Therefore, for Silvana, replacing Catarina at university was a sign that she recognized her competence which made her feel proud of herself. In addition to that, Silvana completed the undergraduate course in advance, in just three years. She felt empowered that she was the first in the family to graduate and to complete the Masters and $\mathrm{PhD}$ program

So, with the acceleration of the undergraduate course I graduated before him (her older brother), so that when he graduated I was already in the Masters and so... I even liked to throw that on their face at that time... 'I'll be the first to hold a Master degree, the one who graduated first, the first to hold a $\mathrm{PhD}$ degree' (...). So there was this change from being the black sheep to being the 'white sheep', let's say. (Interview, February, 2015). 
Silvana actively achieved a new discourse identity (Gee, 20002001). Being the 'white sheep' meant being the model student. She had to work hard to sustain this identity

(...) as I realized that I was able, that I had the capacity, I took too much responsibility and sometimes I paid the price for that... (...). During the Masters, my advisor (...) used to say that because we had a scholarship we had to do all the disciplines and go to all the congresses to present papers. At that time I hated that, but then I showed her that I could make it. (Interview, February, 2015).

In her context of work at IFSC, Silvana continues working hard to sustain this identity. She is the pro-active and practical type, and does not wait long to get things done. For her foreign language colleagues, she is the person to whom they turn to solve institutional or bureaucratic doubts. For other colleagues higher in the department's hierarchy, Silvana is considered a reliable, responsible and efficient professional who they keep resorting even though she is no longer the spokesperson for the foreign language office.

According to Connelly \& Clandinin (1999), a teacher's identity, i.e., her story to live by, is composed of both her personal practical knowledge and the sacred stories of her out-of-classroom place and the secret and cover stories of her in-classroom place. By analyzing Silvana's professional knowledge landscape, i.e., the stories of her outof-classroom and in-classroom places at IFSC, it is possible to weave interpretations regarding the conditions under which Silvana's story to live by is composed, sustained and changed.

When Silvana starts working at IFSC, she does not know exactly what the school's sacred stories are. She enters this new landscape with her own story to live by, a story which she composed little by little with each experience she had since childhood up to that moment and in the various contexts where she had been. Based on the evidences we have of the origins of Silvana's professional identity, such as her family life, school life (both regular and private language school), professional education life, teaching life (prior to IFSC), it is possible to state that she composed a story of the friendly, fun, dedicated and at the same time overly open-minded teacher, who is not romantic towards 
her profession, but faces it as a means of obtaining a good financial return. In addition to that, having worked primarily in private language institutions, for Silvana being an English teacher means getting involved in classroom and teaching issues only, besides receiving the necessary pedagogical support. However, IFSC's out-of-classroom place is filled with requirements and prescriptions ${ }^{10}$ regarding what is right or wrong, what should be done or not, which Silvana did not expect.

In her first day of class, Silvana was not introduced to the school story as it used to be done in the other schools where she worked. She fell into a school landscape in which she felt completely lost and where she received absolutely no pedagogical orientation. In addition to that, she was invited to live a number of other different stories which differed dramatically from her own story to live by. Overnight, Silvana found herself having to live the story of the ESP teacher which she had never lived before. She was also expected to live the story of the 'multilevel' teacher and cope with the specificities required from secondary education classes, integrated and subsequent courses classes, higher education classes and young people and adult education classes, which very often take place in a same day. When CEFET became IFSC, the school story changed too. Now, teachers do not teach to secondary education anymore, but they should get involved and develop research and extension projects. Therefore, Silvana is also supposed to live the story of the researcher teacher. This list of stories Silvana was invited to live by translate into the dilemmas she experienced in the teaching landscape more specifically. According to Connelly \& Clandinin (1999), dilemmas occur when teachers' story to live by shocks with, or a modification of this story is implied or required by institutional life. In other words, teachers' felt dilemmas "are connected to the discrepancies each experiences between her identity and the formal curricular expectations of her role" (Connelly \& Clandinin, 1999:85). That shock or modification on a teacher's identity may lead her to align to the curricular expectations or to insist on her own identity. In the case of Silvana, she opted to align because she wanted to belong to the community of practice of IFSC teachers. As Wenger (1998:179) puts

10. These requirements and prescriptions are stated in official documents, such as IFSC's institutional development plan (PDI), didactic-pedagogical regulation (RDP), IFSC's general regulation (RG) and the Regulation of teaching activities (Regulation 13). 
it, "Through alignment, we become part of something big because we do what it takes to play our part".

Silvana also experienced dilemmas in other spaces of the out-ofclassroom place. After approximately two years working at IFSC, she was persuaded to live a story which caused her distress: to take the role of coordinator of the integrated technical courses. For Silvana, "it was the worst thing I've ever done!! I didn't want to do that (...) I told her 'Look, I've never done that, I haven't studied to be a coordinator. My job is to be in the classroom" (Interview, February, 2015). Silvana was willing to align to some aspects of her institutional identity (Gee, 2000-2001), but not others. She wanted to belong to some communities of practice, but not others. Being a coordinator was definitely a story she did not want to live by and in the first opportunity she left that position. Another school story that Silvana was frequently invited to live by is that of spokesperson for the foreign language office. Initially, Silvana accepted to live this story and became a participant member of that community of practice. However, she depended on the engagement of other members of that community in order to fully live that identity, which did not happen. Therefore, she started to get deeply frustrated with not being able to live this story effectively, as I wrote in my field notes during a teachers' meeting "She is tired of doing the same things a thousand times (...) In another moment she mentioned, privately, (...) she was sick and tired of simple things not working properly, and of people not doing their jobs they way they should" (Field Notes, December, 2014). Silvana also blames on what comes down the conduit, such as excessive bureaucracy and hierarchy. Still regarding what comes down the conduit, Silvana feels outraged and deeply laments the fact that she has seen the team of foreign language teachers lose their language laboratory twice since she started working at IFSC. As a result, Silvana gave up the position, asking for another language teacher to take the role of spokesperson.

Going through the experience of motherhood seems to be another developmental aspect of Silvana's professional identity. She seems to have developed the ability to look at the other with empathy at the same time she can notice the reflection of herself on the other and this promoted changes in her relationship with both students and colleagues 
She had kids (talking about another teacher) and it didn't enter my head why couldn't she work at night (...) And I thought (...) 'That's not the institution's problem that you don't have a babysitter' (...) but nowadays I see. (Interview, February, 2015).

(...) my interaction with the students, my way of seeing things, my way of looking at them changed a lot after I became a mother. (...) And you start to think "I wonder if it's not his (the teacher) attitude towards the students that is making them to behave like this" (...) And I started to think 'I won't do that with mine! I'll check if it works this way, if it doesn't, I'll try another way'. (Interview, February, 2015).

However, motherhood also brought her a dilemma between living the story of the mother and watch closely her kids grow up or the story of the full time teacher. Similarly to what Connelly \& Clandinin (1999:92) found in their study, Silvana "questions her identity because both plotlines in her head are ones she believes she should live by. Yet, these are in conflict". For the time being, Silvana chooses to live the story of the full time teacher.

Overall, Silvana feels happy for working in an institution where, besides inviting her to live some stories which she feels like an imposition, she celebrates feeling free to fully live her story to live by in the in-classroom place. In her in-classroom place Silvana lives her identity of fun, dedicated and overly open-minded teacher. Regarding ESP teaching, that is a secret story that Silvana is slowly composing based on the feedback of students and advice from other teachers. For Connelly \& Clandinin (1999:2), "classrooms are, for the most part, safe places, generally free from scrutiny, where teachers are free to live stories of practice". In addition to that, Silvana recognizes and appreciates that the out-of-classroom place at IFSC is a place where teachers are invited to participate in the elaboration of part of what comes down the conduit, i.e. institutional pedagogical documents, such as the courses' political pedagogic project. In this case, even though teachers should use federal official documents ${ }^{11}$ as a reference, they are relatively free to design such documents in a way that better matches with the needs and specificities of their context.

11. Such documents refer to the Law of Directives and Bases of National Education (LDB) and National Curricular Parameters (PCN). 
According to Wenger (1998:154), referring to identity as inside trajectory, "new events, new demands, new inventions, and new generations all create occasions for renegotiating one's identity". In fact, ever since new English language teachers joined the community of practice of foreign language teachers in 2013/2 and 2014/1, each bringing their views and contributions regarding language, teaching and language teaching, Silvana started to invest more in herself as a teacher. The foreign language teachers also developed a project in order to offer continuing education to foreign language teachers from public schools, besides attempting to design a MATESOL program to be offered at IFSC. Sharing these stories with the teachers seems to have motivated Silvana to envisage a new story to live by, as reflected in her initiatives of searching for current topics in the area of additional language teaching and learning, joining two additional language teachers associations and participating in a congress this year in São Paulo. As Connelly \& Clandinin (1999:102) put it, "when teachers come together and share stories, new stories to live by can also be composed".

Finally, Silvana feels that she needs to write a new story to live by in order to better adapt to her context of work. In her point of view, it is not possible to live the story of Silvana as a researcher in the area of Phonetics and Phonology and the story of Silvana as an English teacher of secondary, technical and technological education simultaneously. She must choose one but she is still in the process of composing this new story to live by, as we can see in her words

(...) now I feel like advising (students in research projects) (...) but it didn't occur to me, like... 'what am I gonna do?' (...) I think we end up changing the area of what we studied during $\mathrm{PhD}$ (..) my area was too specific on pronunciation, phonetics, these things... I feel, I can see myself changing area (of research) in order to adapt. I'm feeling like this. That's why I was so excited to go to that congress, in order to learn about things which I didn't really learn during my teacher education program (Interview, February, 2015).

\section{Final Remarks}

The objective of this study was to weave interpretations regarding the process of Silvana's professional identity (re)construction, an 
English language teacher of secondary, technical and technological education from IFSC. In order to do so, we have not only taken into consideration Silvana's narratives of her past and present life and plans for the future, but have also taken the role of participant observer, participating in her professional life at IFSC for a year and a half. The analysis of data allowed us to corroborate the multiple, multifaceted, shifting, contextual and relational nature of identity (Hall, 1996; Gee, 2000-2001; Varguese, 2005; e Block, 2007). As we could notice, the process of Silvana's professional identity construction was influenced by her previous experiences as a student and also involved her (re) negotiation of identity through participation and non-participation in communities of practice when she was still a student in private language schools and at university.

In addition to that, through the analysis of the different sources of data, we could gain a clearer idea of the conditions under which Silvana's professional identity, i.e., her story to live by was composed, sustained and changed (Connelly \& Clandinin, 1999). The origins of Silvana's professional identity are marked in her family, school and professional education lives and reflected in the different stories she lives at IFSC. Silvana had to work hard to get rid of her black sheep ascribed identity and achieve the 'white sheep' identity which she sustains through her dedication and efficiency in her context of work. When Silvana starts working at IFSC she experiences dilemmas as she is invited to live a number of different stories, some of which she faces as a challenge and aligns while others cause her suffering and frustration and she turns down. Choosing between living the story of the mother or the story of the full time teacher is another source of dilemma in her life. Despite the dilemmas and frustrations, Silvana is satisfied for being able to live her professional identity in the inclassroom place at IFSC and appreciate that the out-of-classroom place is a place where teachers participate in the elaboration of part of what comes down the conduit. Finally, sharing new stories with other English language teachers has motivated Silvana to envisage a new story to live by. Currently, she finds herself in the process of composing this new story to live by which she does not know exactly what it is, but that she know she must make a choice. 
As became evident in the analysis of the data, there is a complex web of issues that interact in the process of Silvana's professional identity construction. Some of these issues refer to happenings in her childhood, experiences of learning, experiences of teaching prior to IFSC, experiences of teaching at IFSC, participation and nonparticipation in communities of practice, transposing of ascribed or imposed identities, and felt dilemmas. The entire process involves a movement of construction, deconstruction and reconstruction which take shape as her life unfolds and which is strongly influenced by her professional landscape.

The present study hopes to contribute to a better understanding of the complexities involved in the process of English language teachers' professional identity construction from IFSC. By bringing a more socially sensitive look at this issue, it also hopes to provide useful information to the (re)design of language teacher education programs and to the very institution's body of knowledge concerning its educational/pedagogical context, since IFSC is also responsible for offering continuing education to its teaching staff. Finally, this study also hopes to fill a gap in the literature regarding research on the process of additional language teachers' identity construction in the context of a federal institution of professional and technological education. In doing so we hope that this work sheds light on some of the factors that might interact in the process of teachers' identity (re) constructions, how these factors interact and the outcomes of such interactive processes. Due to space and time constrains, the present study could not include a discussion of issues such as power relations and agency, which also participate in the process of Silvana's identity construction. Further studies may contribute to the investigation of English language teachers' identity construction in the context of IFSC by addressing such issues.

Recebido em junho de 2016

Aprovado em janeiro de 2017

E-mails: fernanda.machado@ifsc.edu.br glorigil@gmail.com 


\section{References}

Assis-Peterson, Ana Antônia de \& Silva, Eladyr Maria Norberto. 2010. "Não tenho estoque de sonhos para me manter em pé": construção de identidades de uma professora de inglês. In: BARros, Solange Maria de; Assis-Peterson, Ana Antônia de (Org.). Formação crítica de professores de línguas: desejos e possibilidades. São Carlos: Pedro \& João Editores. p. 145-174.

Assis-Peterson, Ana Antônia. 2008. Línguas Estrangeiras: para além do método. In: Assis-Peterson, Ana Antônia de (Org.). Línguas Estrangeiras para além do método. São Carlos, SP: Pedro \& João Editores/Cuiabá, MT/EdUFMT. p. 09-16.

AtAY, Derin \& EcE, Ayse. 2009. Multiple Identities as Reflected in EnglishLanguage Education: The Turkish Perspective. Journal of Language, Identity \& Education. Vol. 8 (1): 21-34.

Barcelos, Ana Maria Ferreira \& Coelho, Simone Henriques. 2010. Emoções, reflexões e (trans)form(ações) de alunos, professores e formadores de professores de línguas. Campinas, SP: Pontes Editores.

Barros, Solange Maria \& Assis-Peterson, Ana Antônia de. 2010. Formação crítica de professores de línguas: desejos e possibilidades. São Carlos: Pedro \& João Editores.

BLock, David. 2007. Second language identities (Chapter 5). London: Continuum International Publishing Group.

Borg, Michaela. 2004. The apprenticeship of observation. ELT Journal. Vol. 58(3): 274-276.

BRASIL. 2008. Lei n ${ }^{\circ} 11.892$, de 29 de dezembro de 2008. Institui a Rede Federal de Educação Profissional, Científica e Tecnológica, cria os Institutos Federais de Educação, Ciência e Tecnologia, e dá outras providências. Brasília, DF.

Bukor, Emese. 2011. Exploring Teacher Identity: Teachers' Transformative Experiences of Re-Constructing and Re-Connecting Personal and Professional Selves. Unpublished doctoral dissertation. University of Toronto. Retrieved December 10, 2015, from https://tspace.library. utoronto.ca/bitstream/1807/31700/6/Bukor_Emese_201111_PhD_ thesis.pdf

CAstaÑeda, José Alberto Fajardo. 2011. Teacher Identity Construction: exploring the nature of becoming a primary school language teacher. Unpublished doctoral dissertation. Newcastle University. Retrieved December 10, 2015, from https://theses.ncl.ac.uk/dspace/ bitstream/10443/1326/1/Fajardo\%20Castaneda\%2011.pdf 
Connelly, F. Michael \& Clandinin, D. Jean. 1999. Shaping a Professional Identity. Stories of Educational Practice. New York: Teachers College Press.

Croker, Rovert A. 2009. An Introduction to Qualitative Research. In: Heigham, Juanita; Croker, Robert A. (Eds.). Qualitative Research in Applied Linguistics - A Practical Introduction. Palgrave Macmillan. p. 3-24.

DenARdi, Didiê Ana Ceni.; GiL, Gloria. 2015. How do I see myself? What do I want to become? A study on English as an additional language teachers' identity reconstruction. Trabalhos em Linguisitca Aplicada. Vol.54 (1): 137-160.

Denzin, Norman K. \& Lincoln, Yvona S. 2005. Introduction: The discipline and practice of qualitative research. In: Norman K. Denzin \& Yvona S. Lincoln (Eds.). The sage handbook of qualitative research $\left(2^{\text {nd }}\right.$ ed.). Thousand Oaks, CA: Sage.

DöRNYEI, Zoltán. 2007. Research Methods in Applied Linguistics. Oxford: Oxford University Press.

Gamero, Raquel. 2011. Identidade Profissional do Professor de Inglês: Um levantamento de dissertações e teses de 1985 a 2009. In: REIS, Simone; van Veen, Klaas.; Gimenez, Telma (Org.). Identidades de professores de línguas. Londrina: Eduel. p. 83-104.

GeE, James Paul. 2000-2001. Identity as an Analytic Lens for Research in Education. Review of Research in Education. Vol. 15: 99-123.

Hall, S. 1996. The Question of Cultural Identity. In: S. Hall, D. Held, D. Hubert \& K. Thompson (ed.). Modernity: An Introduction to Modern Societies (p. 595-634). Cambridge: Blackwell.

HolLidAY, Adrian. 2007. Doing and Writing Qualitative Research. London: Sage Publications.

Kanno, Yasuko \& Stuart, Christian. 2011. The development of L2 teacher identity: Longitudinal case studies. Modern Language Journal, 95(2): 236-252.

Lortie, Dan. 1975. School Teacher: A Sociological Study. London: University of Chicago Press.

Martin, I. \& Morgan, B. 2015. Preparing teachers for "unequal Englishes": The D-TEIL experience in Cuba. In: R. Tupas (Ed.), Unequal Englishes: The politics of Englishes today, Palgrave McMillan. p. 244-264.

Mattos, Andrea Machado de Almeida. 2014. Educating Language Teachers for Social Justice Teaching. Interfaces Brasil/Canadá. Canoas. Vol.14 (2):125-151. 
MinistÉRIO DA EdUCAÇão. 2015. Expansão da rede federal de educação profissional, científica e tecnológica. Retrieved July 15, 2015, from http://redefederal.mec.gov.br/index.php

Morgan, Brian. 2004. Teacher identity as pedagogy: Towards a fieldinternal conceptualization in bilingual and second language education. International Journal of Bilingual Education and Bilingualism, vol.7: 172-188.

2015. Teaching for market-place utility: Language teacher identity and the certification of adult ESL teachers in Ontario. In Y. L. Cheung, S. B. Said, \& K. Park (Eds.). Advances and current trends in language teacher identity research, Routledge: 235-249.

PAVLENKo, Aneta. 2003. "I never knew I was bilingual": Re-imagining teacher identities in TESOL. Journal of Language, Identity and Education, vol. 2: 251-268.

Quevedo-Camargo, Gladys; El Kadri, Michele Salles; Ramos, Samantha Mancini. 2011. Identidade do professor de língua inglesa: um levantamento eletrônicos das pesquisas no Brasil. In: REIs, Simone; van Veen, Klaas.; Gimenez, Telma (Orgs). Identidades de professores de linguas. Londrina: Eduel. p. 47-82.

Reis, Simone; van Veen, Klaas; Gimenez, Telma. 2011. Identidades de professores de línguas. Londrina: Eduel.

Silva, Marimar da; Greggio, Saionara.; Lucena, Camila Araújo; Denardi, Didiê Ana Ceni.; GIL, Gloria. 2007. Narratives: Unveiling Teachers' Identity. Signum: Estudos da Linguagem, Londrina, n.10(2): 199-222.

Telles, João A. 2004. Reflexão e identidade profissional do professor de LE: Que histórias contam os futuros professores? Revista Brasileira de Lingüística Aplicada. Vol. 4 (2): 57-83.

Trejo-Guzman, Nelly Paulina. 2010. The Teacher Self Construction of Language Teachers. Unpublished doctoral dissertation. University of Exeter.

Tsui, Amy B.M. 2007. Complexities of identity formation: A narrative inquiry of an EFL teacher. TESOL Quarterly. Vol. 41: 657-680.

Varghese, Manka; Morgan, Brian; Johnson, Bill \& Johnson, Kimberly. 2005. Theorizing language teacher identity: three perspectives and beyond. Journal of Language, Identity and Education. Vol.4 (1): 21-44.

Wenger, Etienne. 1998. Communities of practice: Learning, meaning, and identity. Cambridge: Cambridge University Press.

Zacharias, Nugrahenny T. 2010. The Teacher Identity Construction of 12 Asian ES Teachers in TESOL Graduate Programs. The Journal of Asia TEFL. Vol.7 (2), p. 177-197. 